
internationales

vol. $19-n^{\circ} 3 \mid 2003$

Moyen-Orient : mutations récentes d'un carrefour migratoire

\title{
The Place of Egypt in the regional migration system as a receiving country
}

\section{Ayman Zohry}

\section{(2) OpenEdition}

\section{Journals}

Electronic version

URL: https://journals.openedition.org/remi/2664

DOI: $10.4000 /$ remi.2664

ISSN: $1777-5418$

\section{Publisher}

Université de Poitiers

\section{Printed version}

Date of publication: 12 December 2003

Number of pages: 129-149

ISBN: 2-911627-35-0

ISSN: 0765-0752

\section{Electronic reference}

Ayman Zohry, "The Place of Egypt in the regional migration system as a receiving country", Revue européenne des migrations internationales [Online], vol. 19 - n³ | 2003, Online since 09 June 2006, connection on 14 April 2022. URL: http://journals.openedition.org/remi/2664 ; DOI: https://doi.org/ 10.4000/remi.2664

This text was automatically generated on 14 April 2022.

(c) Université de Poitiers 


\title{
The Place of Egypt in the regional migration system as a receiving country
}

\author{
Ayman Zohry
}

1 Historically, Egypt was a land of immigrants not emigrants (Sell, 1988). Egypt has been an area of international migration (migration from the eastern and the north-eastern Mediterranean countries to Egypt). In the past, foreigners were coming to Egypt while Egyptians rarely migrated abroad till the mid 1950s. The ancestors of the Egyptian people include many races and ethnic groups, including Africans, Arabs, Berbers, Greeks, Persians, Romans, and Turks. This paper surveys Egyptian immigration with emphasis on emigration to complete the picture. The study is migrant-focused, though some elements of Egyptian government policy are also included. Sections on migration to Egypt focus mainly on refugees, using as examples the largest populations from Palestine, Sudan, Ethiopia, and Somalia, because they form the majority of new migrants to Egypt. These sections are primarily concerned with the policies of the Egyptian government and the United Nations High Commissioner for Refugees (UNHCR), which decides refugee status in Egypt. To take a migrant-focused approach to immigrants - mainly refugees - who come from at least 30 different countries, would require political and economic analyses of their countries of origin, and this is beyond the scope of this study.

2 The dominant geographical feature of Egypt is the River Nile. The Nile represents the main source of water for agriculture, and consequently is a major determinant of the spatial distribution of population and economic life. Rapid population growth is one of the crucial problems that hinder development efforts in Egypt. While the doubling of Egypt's population between 1897 and 1947, from 9.7 million to 19 million, took fifty years, the next doubling took less than thirty years, from 1947 to 1976. Today, Egypt's population approaches 70 million. The annual population growth rate is around $2 \%$. About $95 \%$ of the population is crowded onto around the $5 \%$ of the total land area that is formed by the narrow ribbon of dense population and agriculture that follows the 
course of the Nile. The remaining $95 \%$ of the land is desert. Although it can be seen as a kind of 'natural response' to the geography of economic opportunity, migration to large cities has further imbalanced Egypt's population distribution.

3 Associated with rapid population growth is a high level of unemployment. Official estimates placed unemployment at about 8.4 percent in 2000/2001 down from 9.2 percent in 1991/1992. Independent estimates push the number to 14 percent (Zohry, 2002). However, to control unemployment, Egypt will need to achieve a sustained real GDP growth rate of at least 6 percent per year. The economy has to generate between 600,000 and 800,000 new jobs each year in order to absorb new entrants onto the labor force. Between 1990 and 1997, however, only about 370,000 new jobs were created each year. The size of the informal sector and the level of over-employment in the public sector add to the complexity of the problem.

4 This study relies mainly on secondary data. Primary data come from my observations and informal interviews with senior officials in the Ministry of Manpower and Emigration while working as a consultant in the Integrated Migration and Information Systems project (IMIS). It should be borne in mind that migration data are generally incomplete, based more on estimates than hard facts, so that even simple trends are often hard to confirm.

\section{Egypt's international emigration}

\section{Historical development}

5 International migration has always been considered a demographic and socio-economic phenomenon, which is affected by both internal and external factors. The most important among these factors is the labor market at the international level and the political conditions in both sending and receiving countries (Choucri, 1999). Egyptian government policy toward migration has gone through different phases. Phases are defined by changing international conditions and international labor market needs, particularly in the Arab region. These phases overlap and the beginning and ending points of each phase are not discrete. There are no standard phases in the Egyptian migration literature that are agreed upon by all researchers.

\section{Phase 1 : The early phase of migration (before 1974)}

6 Historically, Egypt was a land of immigrants rather than emigrants. Students went abroad in the nineteenth century and some temporary migration for political reasons occurred in association with early Egyptian nationalism. However, systematic migration started only with Egypt's provision of school teachers to Iraq in the 1930s, a program that spread to additional countries after the 1952 revolution (Sell, 1988). Until about 1961 other migration policies mostly concerned immigrant issues, such as the legal status of the non-Egyptian heritage population. Little attention was paid to Egyptians who left or wanted to leave. Political controls on migration were in force, mainly through 'exit visa' requirements (Choucri, 1977).

7 Egyptians' interest in migration began in the mid-1950s. This was due to political, demographic, and economic pressures. The government was motivated to bear the burden by providing job opportunities. However, increasing population growth, along 
with the lack of growth in the economic and technological sectors, diminished the state's ability to provide jobs. However, this phase was characterized by virtual fullemployment, as unemployment rates were very low.

8 After 1967, many factors combined to motivate the state to promote migration. The state had previously imposed restrictions on the migration of skilled workers, but in mid-1966 it eased migration procedures and permanent migration commenced. Many graduate students were tempted to stay abroad due to unfavorable economic conditions at home after the 1967 war. This was the start of the Egyptian 'brain drain'.

In 1971, permanent and temporary migration was authorized under Article 52 of the 1971 Constitution, which stated that 'all Egyptians were granted the right to emigrate and to return home'. Also in 1971, the government issued Law 73, which gave public sector employees the right to return to their jobs within one year of resignation. This was then extended to two years and other legal impediments were removed. Large numbers of temporary migrants began to work in the Arab Gulf countries.

\section{Phase 2 : The expansion phase (1974-1984)}

10 The expansion phase started directly after the 1973 war. The oil embargo led to a large increase in oil prices, which was followed by ambitious development programs in the Arab oil-producing countries. This situation increased the demand for Egyptian labor. The number of Egyptian emigrants was estimated by the Central Agency for Public Mobilization and Statistics (CAPMAS) to be about 70,000 in 1970. By 1976 the figure had increased to about 1.4 million according to that year's census.

11 During this period, the government further eased migration procedures. Migration became a top priority for the following reasons: to solve unemployment problems, to use remittances to supply payment deficits and finance private projects, to supply Arab countries with required labour, to relieve pressure caused by political and economic factors.

There was a sense of stability in relation to labor migration as a result of government agencies responsible for organizing labor migration.

Increasing demand for teachers became evident in other Arab countries during this phase. Government supported migration from the health sector, including doctors, veterinarians, pharmacists, and dentists. Iraq became a favored destination for unskilled labor due to its liberal immigration policies towards fellow Arabs, and its need for foreign labor as a result of the war against Iran.

Cheaper Asian and South Asian labor began to migrate to the labor-importing Arab countries, threatening Egyptian workers. As a result, Presidential Decree No. 574 of 1981 established the Ministry of State for Emigration Affairs. This new ministry sponsored Egyptians going abroad and provided them with a number of services. In addition, it drew up an overall migration strategy aimed at national development.

\section{Phase 3 : The contraction phase (1984-1987)}

15 The contraction phase begins around 1983 after the start of the Iran-Iraq war, which depressed oil revenues. From 1983, the number of Egyptian emigrants became smaller and smaller. Since the second half of 1980s, Egyptian migrant labour faced a number of new problems: end of the Iran-Iraq War in 1988, fall of oil prices, declined demand for 
construction workers in Arab countries, policy of replacing foreign labour with nationals in the Arab Gulf states.

During this period, skilled workers migrated to the labour-importing countries to replace the unskilled workers who had been dispensed with. Some countries implemented schemes to provide training for national workers to reduce the dependence on foreign labour. The promulgation of the Emigration and Sponsoring Egyptians Abroad Law $N^{\circ} 111$ of 1983 was one of the most important outcomes of this period. This law is regarded as the main migration law in Egypt.

\section{Phase 4 : The deterioration phase (1988-1992)}

This stage was characterized by a significant flow of return migrants from the Gulf area to Egypt and a continuous decline in the number of contracts granted to new emigrants from Egypt. Considering 1988 as a base year, the number of contracts halved in 1989. This big decline was due to the decrease in the number of contracts with Jordan, Iraq, Yemen, Saudi Arabia, and other Arab Gulf countries. In 1990, the number of contracts further decreased to $43 \%$ (of the base year 1988). In 1990, however, contracts with Saudi Arabia and Libya increased.

The 1990 Gulf War forced almost all Egyptian immigrants in Iraq and Kuwait to return to Egypt.

\section{Phase 5 : The immigration phase (1992-2003)}

19 After the Gulf War, migration rates returned almost to the status quo ante the beginning of the war. Receiving countries wanted to minimize the number of immigrants. Moreover, many returned migrants settled down in Egypt. The main feature of this phase that it witnessed a massive migration flows to Egypt from neighbouring African countries due to conflict and political instability in the Sudan and some other SubSaharan Africa.

\section{Volume of Egyptian emigration}

'Egyptians have the reputation of preferring their own soil. Few ever leave except to study or travel; and they always return... Egyptians do not emigrate' (Cleland, 1936: 36, 52). This was the case until the middle of the twentieth century with few exceptions. Only small numbers of Egyptians, primarily professionals, had emigrated before 1974. Then, in 1974, the government lifted all restrictions on labour migration. The move came at a time when Arab Gulf states and Libya were implementing major development programmes with funds generated by the quadrupling of oil revenues in 1973. The number working abroad in the Arab region around 1975 reached about 370,000 as part of about 655,000 total migrants (Brinks and Sinclair, 1980). By 1980 more than one million Egyptians were working abroad. This number more than doubled by 1986 with an estimate of 2.25 million Egyptians abroad (CAPMAS, 1989). The emergence of foreign job opportunities alleviated some of the pressure on domestic employment. Many of these workers sent a significant portion of their earnings to their families in Egypt. As early as 1979 , these remittances amounted to $\$ 2$ billion, a sum equivalent to the country's combined earnings from cotton exports, Suez Canal transit fees, and tourism. 
21

foreign demand for Egyptian labour peaked in 1983, when an estimated 3.3 million Egyptians workers were employed abroad. After that year, political and economic developments in the Arab oil-producing countries caused a cutback in employment opportunities. The decline in oil prices during the Iran-Iraq War forced the Arab Gulf oil industry into a recession, which cost some Egyptians their jobs. Most of the expatriate workforce remained abroad but new labour migration from Egypt slowed considerably. But in the early 1990s, the number of Egyptian workers abroad still exceeded 2.2 million.

The majority of Egyptian labour migrants are expected to return home eventually, but thousands left their country each year with the intention of permanently resettling in various Arab countries, Europe, or North America. These emigrants tended to be highly educated professionals, mostly doctors, engineers, and teachers. Iraq was the Arab country most likely to accept skilled Egyptians as permanent residents. Iraq, which sought agricultural professionals trained in irrigation techniques, encouraged Egyptian farmers to move to the sparsely populated but fertile lands in the south. Outside of the Arab countries, the United States was a preferred destination.

\section{Temporary migration}

'Egypt is now experiencing what is called the permanence of temporary migration' (Farrag, 1999: 55). In the last three decades, flows of temporary migrants to neighbouring Arab countries exceeded permanent migration to Europe and North America. Official secondment through governmental authorities on the basis of bilateral contracts is one of the main forms of temporary migration. Travel through official channels increased in the last two decades as an alternative form of migration. Working in branches of Egyptian companies, especially in the construction sector, was one of the channels of temporary migration.

24 According to the official estimates of the Central Agency for Public Mobilization and Statistics (CAPMAS), the total number of Egyptian temporary migrant labourers is about 1.9 million. Most of the demand for Egyptian labour comes from Saudi Arabia, Libya, Jordan, and Kuwait. Migrants to these countries comprise $87.6 \%$ of the total number of Egyptian migrant labourers. In the most recent years, and after the end of its civil war, Lebanon became a new destination for unskilled Egyptian migrants who work mainly in construction (See Table 1). 
Table 1 : Temporary Egyptian Migration by Receiving Country

\begin{tabular}{|l|c|c|}
\hline Receiving Country & Number of migrants & Percentage \\
\hline Saudi Arabia & 923,600 & 48.3 \\
\hline Libya & 332,600 & 17.4 \\
\hline Jordan & 226,850 & 11.9 \\
\hline Kuwait & 190,550 & 10.0 \\
\hline UAE & 95,000 & 5.0 \\
\hline Iraq & 65,629 & 3.4 \\
\hline Qatar & 25,000 & 1.3 \\
\hline Yemen & 22,000 & 1.2 \\
\hline Oman & 15,000 & 0.8 \\
\hline Lebanon & 12,500 & 0.7 \\
\hline Bahrain & 4,000 & 0.2 \\
\hline Total & $1,912,729$ & 100.0 \\
\hline
\end{tabular}

Source : CAPMAS (2001)

Towards the end of the 1980s, Egyptians in Saudi Arabia and other Gulf countries comprised a much smaller proportion of the foreign workforce than in the late 1970s before major construction projects were completed. In the 1980s, Egyptian workers represented $40 \%$ of the total foreign labour in Saudi Arabia. A smaller workforce was in Bahrain, Kuwait, Oman, Qatar, and the UAE. The fluctuation of the number of migrant labourers to Iraq and Libya in the last three decades was affected by political tensions including the Iran-Iraq War, the Gulf War, and the political and economic sanctions on Libya.

\section{Permanent migration}

From the beginning of the 1960s, political, economic, and social developments led some Egyptians to migrate permanently to America and European countries. According to the estimates of CAPMAS, the total number of permanent Egyptian migrants in nonArab countries is slightly more than 0.8 million $(824,000)$. About $80 \%$ of them are concentrated in five countries: USA (318,000 or $38.6 \%)$, Canada (110,000 or $13.3 \%)$, Italy $(90,000)$, Australia $(70,000)$, and Greece $(60,000)$. The other $20 \%$ are mainly in Western Europe countries, such as Holland, France, England, Germany, Switzerland, Austria, and Spain (See Table 2). 
Table 2 : Estimated Number of Permanent Egyptian Migrants by Country of Destination

\begin{tabular}{|l|c|c|}
\hline Country of Destination & Number in Thousands & Percent \\
\hline U.S.A & 318 & 38.6 \\
\hline Canada & 110 & 13.3 \\
\hline Italy & 90 & 10.9 \\
\hline Australia & 70 & 8.5 \\
\hline Greece & 60 & 7.3 \\
\hline Holland & 40 & 4.9 \\
\hline France & 36 & 4.4 \\
\hline England & 35 & 4.2 \\
\hline Germany & 25 & 3.0 \\
\hline Switzerland & 14 & 1.7 \\
\hline Austria & 14 & 1.7 \\
\hline Spain & 12 & 1.5 \\
\hline Total & 824 & 100.0 \\
\hline
\end{tabular}

Source : CAPMAS (2000) - 'The United Evaluation 2000'

The statistics given by CAPMAS are just estimates which are drawn from the reports of Egyptian embassies abroad, records of cross-border flows from the Ministry of Interior, emigration permits from the Ministry of Manpower, and some other sources. The receiving countries make different estimates than CAPMAS. For example, the Italian government estimates there are around 35,000 Egyptians in Italy whereas CAPMAS gives a figure of 90,000 . Estimates by CAPMAS may need to be revised whenever reliable data are available.

\section{Immigration to Egypt}

\section{Voluntary migration}

According to the latest Egyptian Census of 1996 (CAPMAS, 1999), the number of foreigners living in Egypt reached 116000 . About 94000 of them lived in urban areas, and 22000 in rural areas. They represented only $0.1 \%$ of the total population in the 1996 Census.

Currently, there are several thousand Americans, Europeans, and other non-Arabs in Egypt working on projects sponsored by foreign governments, international agencies, and private charitable groups. The United States stationed more than 2,000 diplomatic personnel in the country. The majority of these personnel are working for the United States Agency for International Development (USAID), which managed the largest of the many socioeconomic aid programs in Egypt (Library of Congress, 2003).

According to the Egyptian labor regulations, the number of non-Egyptian employees in any establishment must not exceed $10 \%$ of the total work force for unskilled or semiskilled workers. For skilled workers the limit of foreigner labor is 25 percent. The Egyptian labor market is regulated by the Labor Law No.137 for 1981. However, a new "Unified Labor Law" has been drafted and is currently under parliamentary discussions. The proposed law comprises 270 articles that address all the legal aspects regulating the Egyptian labor market. The new law aims at increasing the private sector involvement and at the same time achieving a balance between employees' and employers' rights. 

the corresponding regulations issued by the Ministry of Manpower and Migration in this regard. After a work permit is obtained, the foreign national's visa (whether tourist or temporary) is converted into a work visa, with the same duration as the work permit.

Werk permits are easier to obtain for technical staff than for unskilled or semi-skilled workers. Work permits are usually granted to foreigners for a period of ten months after which they are usually easily renewed.

The percentage of working foreigners in Egypt was about $28 \%$ of the total foreigner population 15 years and over who were captured in the 1996 Census. More than half of the employed resident foreigners came from Arab countries (58.1\%), followed by those who came from Europe (21\%), from Asian countries (6\%), and from North America (6\%). At the time of the 1996 Census, $71 \%$ percent of the working foreigners were working in the private sector.

With respect to the occupational composition of the working foreigners, about $25 \%$ of them were specialists (scientific occupations), followed by professionals, technicians and managers (17\%). About $10 \%$ of the working foreigners were assistants of technicians and specialists. The same percentage applies to craftsmen and services and sales. Eight percent were involved in agriculture. Working foreigners who work in other occupations represent a small percentage.

The total number of work permits for foreign workers in Egypt in the year 2002 was 17,897 . Some 5,005 of this number were first time permits, and the remainder $(12,892)$ was for renewals. Work permits for nationals of Arab countries comprise about $50 \%$ of the total work permits issued in the year 2002, followed by European countries nationals (26.3\%), and Asian countries national (14\%). This geographical distribution of foreign workers in Egypt is consistent with the findings of the 1996 Census results presented in the previous section - regarding the percentage distribution of foreign national employees, except the noticeable increase of Asian countries nationals who work in Egypt. This may suggest that a slight change in the pattern of foreign employment in Egypt occurred between 1996 and 2002 (See Table 3).

Table 3 : Number of Work Permits Issued for Foreigners in Egypt by Type of Permit and Main Nationality Groups (2002)

\begin{tabular}{|l|r|r|r|r|}
\hline \multirow{2}{*}{ Nationality Groups } & & Type of Permit & & \multirow{2}{*}{ Percent } \\
\cline { 2 - 4 } & First Time & Renewals & Total & \\
\hline Arab Countries & 1487 & 7395 & 8882 & 49.6 \\
\hline African Countries & 57 & 91 & 148 & 0.8 \\
\hline Asian Countries & 923 & 1574 & 2497 & 14.0 \\
\hline European Countries & 1919 & 2795 & 4714 & 26.3 \\
\hline Americas and Australia & 520 & 900 & 1420 & 7.9 \\
\hline Other Nationalities & 99 & 137 & 236 & 1.3 \\
\hline Total & 5005 & 12892 & 17897 & 100.0 \\
\hline
\end{tabular}

Source : Ministry of Manpower and Emigration 


\section{Forced Migration (Refugees) ${ }^{1}$} 53 states that 'Egypt is obliged to grant the right of political asylum to any foreigner who has been persecuted for his defense of the interests of people, or of human rights, peace or justice.' The Office of the President is in charge of granting asylum to political refugees. However, little is known about the procedures for qualifying as a 'political refugee' (No Author, 2002). It seems mainly reserved for certain high-profile cases such as the Shah of Iran, Jaafar Nimeri of Sudan, or the wife of the last king of Libya. The Palestinian refugees are regulated by a separate office. When they apply for residence permits, their cases are treated separately by the interior ministry. force of law and in all cases supersede domestic law. In 1951, Egypt was, with Turkey, the only non-western member of the drafting committee of the UN Convention on Refugees. UNHCR established its office in the country in 1954.

In 1980, Egypt ratified the Organization of African Unity Convention Governing the Specific Aspects of Refugee Problems and the 1951 UN Convention. In 1981 it ratified the 1967 Protocol. In 1984, it ratified the African Charter on Human and Peoples' 
Rights, which also provides for the right to seek and obtain asylum. The Arab Declaration in 1992 also urged Arab States to adopt a broad concept of 'refugee' and 'displaced person' as well as a minimum standard for their treatment, guided by the provisions of the United Nations instruments relating to human rights and refugees as well as relevant regional instruments, and to also guard against refoulement (Grindell, 2003).

42 At the time of ratifying the 1951 Convention, Egypt entered reservations to the following articles, making them inapplicable in Egypt: Articles 12.1; 20; 23; and 24. These cover personal status, unequal treatment of refugees compared to national if there is a rationing system in Egypt; and access to public relief, but the two articles having the greatest impact on refugee populations living in Egypt are Article 22 on free primary education and Article 24 on employment. For these reasons alone refugees in Egypt have no chance for 'integration', one of UNHCR's three 'durable solutions'.

Egypt is a signatory of the 1989 UN Convention on the Rights of the Child which stipulates that children have the right to free access to education and support for psychological recovery after war. Nevertheless primary and secondary education for most refugees is not allowed in Egyptian public schools ${ }^{3}$. Until 1978, Palestinians were an exception to this prohibition. Refugees who want a university education must pay foreigners' fees in foreign currency. With the restriction on the right to work, refugees are forced to rely on the informal sector and are thus easily exploited. However, a policy issue open to exploration is Article 17(1), (2) and (3) of the 1951 Convention, to which Egypt did not enter reservations. Article 1 states, 'the Contracting States shall accord to refugees lawfully staying in their territory the most favorable treatment accorded to nationals of a foreign country in the same circumstances, as regards the right to engage in wage-earning employment'.

Despite constitutional provisions concerning refugees, the maintenance of Egypt's reservations to the Convention, the lack of national laws on refugees, and the unwritten non-integration policy of the Egyptian government have all contributed to the hardships of refugees in Egypt. The government has allowed UNHCR to assume the responsibility for refugee status determination. But when UNHCR functions as the decision-maker (or judge) in the decision process, it cannot effectively fulfill its primary mandate of refugee protection ${ }^{4}$. Moreover, there is no judicial review of the status determination procedures and no independent appeal process to which rejected refugees have recourse (Kagan, 2002, 2003a).

Since 1997 there have been 63,243 registered asylum seekers, but only 18,537 have been recognized (of which 12,251 have been resettled). In the past six years over 32,000 claims have been rejected and their files closed by UNHCR. This latter group, who fear to return home, earn a meager living in the informal economy, and live under the constant threat of detention and deportation (Grindell, 2003). The acceptance rate for asylum seekers has varied widely, ranging from $24 \%$ in 1997, to 38 \% in 1998 and 1999, back down to $31 \%$ in 2000 , up to $42 \%$ in 2001, down again to $27 \%$ in 2002 .

Before November 2002, asylum seekers eighteen and older who sought refugee status from UNHCR were given a minute slip of paper that only showed the date of the interview and passport number. It was not stamped by UNHCR and offered no other information. The holder of such a paper is supposed to be regarded as 'under the protection of UNHCR,' but police and security do not recognize it. Since most asylum seekers must wait for more than a year for a decision on their case, they continue to be 
at serious risk of detention or deportation. Since November 2002, new asylum seekers are issued yellow cards. This new card, valid for six months and renewable three times, provides refugees with residency from the Ministry of Interior through the Ministry of Foreign Affairs. Those who are recognized as refugees by UNHCR are issued a blue card that allows them to reside in Egypt. Most recently, the stamp 'work prohibited' has been removed from the residence permit, a significant positive step by the Government of Egypt.

UNHCR has a special relationship with Palestinian refugees. Article 1D of the 1951 Convention excludes any group of refugees who receive protection or assistance from another UN agency. This provision was intended to exclude most Palestinian refugees from UNHCR's mandate, because they had been assisted by UNRWA (see above) since 1948, and it was included at the behest of Arab governments. However UNRWA has never been allowed to operate in Egypt, so Palestinians in Egypt do fall under UNHCR's mandate. Arab countries continue to advocate the exclusion of Palestinians from the mandate of UNHCR and from the 1951 Convention. They are primarily concerned that Palestinians continue to receive special United Nations attention. The Arab governments fear that Palestinian refugees '...would become submerged [with other categories of refugees] and would be relegated to a position of minor importance' (Takkenberg, 1998: 66) ${ }^{5}$. The fear is that Palestinian refugees would effectively forfeit their right to return if UNHCR's 'durable solutions', which include resettlement and integration as well as repatriation, were offered to them. The Palestinian refugee problem, Arab governments argued, was to be resolved with a special formula of repatriation and compensation rather than resettlement to a third state.

Because of Egypt's reservations to the 1951 Convention do not permit refugees to enjoy their basic rights, Egypt is viewed by most refugees as a transit country. There are significant resettlement programs to such countries as Australia, Canada, Finland, and the U.S. From 1997 to May 2003, UNHCR have resettled 12,051 refugees to western countries. This does not include refugees who have managed to get 'sponsorship' to Australia and Canada through special programs. It also does not include refugees who have left Egypt for Libya in order to attempt to reach Italy using traffickers. Somalis are known to take this route, but other groups may also do so. Other refugees use traffickers to reach Israel ${ }^{6}$.

\section{Palestinian refugees ${ }^{7}$}

50 The Palestinians have been subjected to changing policies which have become increasingly restrictive, largely due to the shifts in political relations among the government of Egypt, the Palestine Liberation Organization (PLO), and Israel. The Egyptian media promote a general stereotype of Palestinians as wealthy, though the actual number of the 'wealthy' is very small. Another common and negative media image of Palestinians is that they have brought their troubles on their own heads, having sold their land to the Israelis. It is often speculated that Egypt's restrictive policies towards all refugees in general are a product of its policies towards the Palestinians. 


\section{History of Palestinian refuge}

51 The first Palestinians in modern history to flee to Egypt came in 1929 when violence erupted between Jews and Arabs in the Burak Rebellion. Palestinians also fled the civil strife between 1936-1939 when the Arabs in Palestine tried to halt Zionism. However, the major influxes of Palestine refugees occurred during the 1948 and 1967 wars. In 1948, some 3,000 Palestinians set out for Port Said and Alexandria by boat. Another 10,000 to 15,000 went to Gaza. The Egyptian government responded by setting up camps to receive these refugees.

No official figures on the Palestinians are available from the government. In 2003, according to unofficial sources, there were said to be 50,000 to 70,000 Palestinians in Egypt. According to the newspapers - Al-Wafd, Al-Ahram and Al-Ahram Hebdo - the number of Palestinians in Egypt during the 1990s varied between 80,000 and 100,000. According to the Palestinian ambassador there were 53,000 Palestinians living in Egypt in 2001. The Arab League and the Egyptian Foreign Ministry continue to set the figure at 70,000. Yassin (1996) states that 256,973 Palestinians held Egyptian travel documents in 1994.

53 Today, most Palestinians live dispersed in many villages and towns across Egypt, existing beneath (or even far below) the poverty line. Due to the severe restrictions on education, Palestinians in Egypt are probably the least educated of all the diaspora Palestinians. Repeated Arab League resolutions advising governments to treat them on a par with nationals have not been heeded by Egypt. In 1948, the UN Relief and Works Agency (UNRWA) was established to provide assistance (not protection) to Palestinian refugees in the host states: Jordan, Lebanon, Syria, the West Bank, and Gaza. But UNRWA was never invited to work in Egypt.

In 1948, with the great numbers of Palestinians entering the country through land and maritime borders, an immense camp, Qantara Sharaq, was created in the northeast part of Egypt near the Suez Canal. Another camp, Azarita, was created in the north near Alexandria. Palestinians who desired to leave the camps were required to have an Egyptian guarantor. Subsequent people arrived as individuals or families and found their way to relatives across the country.

In 1950, Egypt's King Farouk signed an agreement with UNRWA to assist Palestinian refugees in Gaza but did not permit them to operate in Egypt. He wished to discourage Palestinians from staying in Egypt on the grounds that Egypt was already 'too crowded with its own people and [could not] receive the refugees on their territories' (El Abed, 2003).

When Gamal Abdel-Nasser became president he addressed the Palestinian issue more favorably. Nasser set up 'employment projects' for the 50,000 Palestinians residing in the Sinai in order to improve their situation. Nevertheless, Palestinian refugees were not allowed to work (except for the British army), open their own businesses, or hold Egyptian passports. In 1954, Nasser allowed Palestinians to work as teachers and in 1962 he passed Law 66 that permitted Palestinians to work in the public sector and 'to be treated as nationals of the United Arab Republic' (El Abed, 2003). In addition to this law, Egypt ratified the Casablanca Protocol in 1965 which pledged to treat Palestinians on par with citizens and to work to preserve the Palestinian identity.

By the late 1970s, these favorable policies toward Palestinians in Egypt were withdrawn. In 1973 President Sadat succeeded in regaining control of the Sinai from Israel, after which he sought to make peace in exchange for economic and military aid 
from the United States. Palestinians saw Sadat's peace negotiations with Israel as unacceptable, and this strained relations between Egypt and the PLO. The assassination of the Egyptian minister of culture by a PLO faction further soured ties.

Later that year, two administrative regulations, Nos. 47 and 48, were issued, rescinding all regulations that gave Palestinians the same rights as nationals. With these special privileges taken away, Palestinians had no more rights than other foreigners. From 1978 until today, they have been prohibited from work in the public and private sectors, they need a permit for any work, they must pay foreigners' fees in hard currency for university education, their rights to travel are severely restricted, and those who overstay travel permits are subjected to deportation or detention.

\section{Travel documents}

In 1948, the Egyptian government began issuing travel documents and birth certificates to Palestinians. One-year residence permits without permission to work were also issued. Travel documents issued after 1960, during the period of Egyptian-Syrian unity, prohibited Palestinians from traveling to Syria without a visas. In 1964, new provisions were made for travel documents, extending their validity to two years. These documents did not permit Palestinians to return to Egypt without re-entry visas issued in advance of departure. Those arriving after the 1967 war were issued travel documents valid for only three years. There are different charges for renewing residence permits, according to the refugee's date of arrival in Egypt. Most important, and despite the fact that Palestinians in Egypt are "who cannot go back to Palestine, being granted residence permits is contingent on providing a reason to remain in Egypt. The only accepted reasons are studies in a recognized educational institution, licensed work, marriage to an Egyptian, or evidence of an Egyptian business partnership.

Those working in (or retired from) government service, the Administrative office of the Governor of Gaza, or the PLO, have the fewest problems renewing residence permits. However, the majority of Palestinians work in the informal sector and face great obstacles. Without a residence permit, Palestinians are subject to detention and deportation. Young men are particularly vulnerable when they reach age eighteen and have been forced to stop school, or have graduated from university but cannot find licensed work. Men in this situation are forced to live illegally in Egypt until they can provide authorities with an official reason for their stay.

61 Palestinians who have traveled out of Egypt, especially those who have gone to Gaza in the hopes of finding employment and have overstayed their six-month re-entry permits, find themselves unable to return ${ }^{8}$. These people are either living illegally in Gaza, or have been imprisoned on return to Egypt if they can find no other country to accept them.

\section{Sudanese refugees}

62 'Sudanese in Egypt have for long enjoyed a status close to nationals on account of a number of bilateral agreements, the most recent being the Nile Valley Agreement of 1976 which inter alia allowed for free movement of goods and people across the common border' (Sperl, 2001: 20). During the civil war from 1955 to 1972, the first wave 
of Sudanese asylum seekers came to Egypt. The second wave of Sudanese began arriving as a result of the current civil war that began in 1983. Most of the recent asylum seekers in Egypt are from Southern Sudan, South Kordofan, and South Blue Nile regions of Sudan. A significant number of Sudanese from the Muslim north have also sought refuge from persecution since 1983. Besides civil war and fear of persecution, some Sudanese have come to Egypt because of famine and the impossibility of sustaining life in the displaced camps around Khartoum (Cooper, 1993: 2).

Until 1995, it was not necessary for Sudanese refugees to seek asylum; they were usually referred to as 'displaced people'. However, the 1995 assassination attempt on President Mubarak in Ethiopia, allegedly by members of Egypt's Islamic fundamentalists supported by the Sudanese government, changed Egypt's open-door policy toward their southern neighbour. Since then, every Sudanese must have a visa to enter Egypt and, if a refugee, must proceed through the refugee status determination process at UNHCR.

In 2001 there were only 2,960 recognized refugees from Sudan. Their recognition rate in 2000 was only $30 \%$ and does not come near to reflecting the true number of Sudanese who have fled their country because of war and persecution.

As with most refugee populations, the Sudanese see education for their children as the only way out of poverty, but they have been barred from the free Egyptian public school system. Christian churches and refugee-run NGOs are the only source of education for refugees in Cairo. Only one of these primary school programs teaches the Egyptian curriculum. There are not nearly enough facilities and resources to educate the tens of thousands of refugee children living in Egypt and there are no secondary schools.

In December 2000 the minister of education announced a plan to address the lack of public primary education for Sudanese children and in 2001 a ministerial decree was issued (Peterson, 2001). The decree is problematic in two ways. Families are required 'to present extensive documentation, including a birth certificate, last schooling level certificate, identity document with legal residence permit, and letter from the Embassy of Sudan' (Peterson, 2001) ${ }^{9}$. A second obstacle is the resistance of the Sudanese refugees to the idea of local integration, preferring English-language teaching no matter how few opportunities are available, as preparation for their hoped-for resettlement to Englishspeaking countries in the West. Their resistance to Arabic teaching is also related to their deep-seated aspirations for an independent Southern Sudan where, as one Sudanese man put it, 'Arabic is not going to be the main language' (Peterson, 2001).

\section{Somali refugees}

67 Prior to the Somali civil war that began in 1991, Somalis residing in Cairo consisted of three main groups: diplomats and their families, university students on scholarships, and female-headed families who came to Egypt for the education of their children while their husbands worked in the Gulf (Al-Sharmani, 2003). According to UNHCR, in 2003 there were 1,832 recognized Somali refugees, 952 rejected applicants, and 1,544 asylum seekers ${ }^{10}$.

68 Somalis who came to Egypt before the war or shortly thereafter differ from those who came to Egypt in the late 1990s. The first Somalis to settle in Cairo came mainly from urban areas, were highly educated, had held professional or administrative jobs, and 
fled Somalia via Kenya or the Gulf. The more recent Somali refugees have both urban and rural origins, are more likely to be unskilled and young. Many are illiterate, and a number of them fled first to the Gulf before coming to Cairo.

Somalis are concentrated in two districts of Cairo, Ard El-Liwa and Nasr City. Because the Somali community in Cairo is 'an integral part of well-connected communities of the transnational Somali Diaspora that have very strong economic and social ties,' many Somalis receive remittances from relatives in western countries and Saudi Arabia, in addition to their income from the informal sector in Cairo (Al-Sharmani 2003).

70 Somalis suffer from the restrictions on attendance of public schools and very few, if any, benefit from the church-based educational programs on offer in Cairo. Self-help schools organized by the Somali Refugee Committee of Egypt (SRCOE), and other small NGO initiatives, provide an alternative for a few children. Also, some Somali households who have resisted resettlement out of fear of cultural assimilation in the West are said to receive more assistance from Caritas, UNHCR's implementing partner for humanitarian assistance to refugees in Egypt. This differential treatment understandably creates tensions within the group.

\section{Ethiopian and Eritrean refugees}

71 From 1977-1979, Ethiopian refugees came to Egypt in order to escape the Mengistu regime's 'Red Terror' (Cooper, 1992a). Another influx of refugees came in 1991-1992 when the Mengistu regime fell. Some were members of the military. The recent border conflict between Ethiopia and Eritrea (1998-2000), the suppression of civil liberties in both countries, and the turndown in the economy are all reasons why Eritreans and Ethiopians have continued to flee to Egypt. Eritrean refugees living in Sudan began coming to Egypt after UNHCR and the Eritrean government invoked the cessation clause (Article 1C(5)) of the 1951 Convention in 2000 because they feared forced return.

The majority of Ethiopians and Eritreans in Cairo during the early 1990s were educated and skilled single young men from urban areas, from both Muslim and Christian backgrounds (Cooper, 1992a). More than half came to Cairo directly by plane while others came by foot or train after having spent some time in other African countries and the Gulf countries. Financial support mainly stemmed from relatives in the West and local churches.

More recent data on the make-up of the Ethiopian and Eritrean refugee population in Egypt are not available. However, if trends from the early 1990s hold true, the profile of refugees from Ethiopia and Eritrea will have greatly changed. Before 1990, men coming from these two countries made up the majority but by 1992 more women than men were fleeing to Cairo.

UNHCR statistics show that as of March 2001, there were only 18 Eritrean and 59 Ethiopian recognized refugees living in Cairo. The recognition rate was $13 \%$ for Eritreans and $14 \%$ for Ethiopians in 2000. Nevertheless, the actual Eritrean and Ethiopian community is around 5,000. Most of their files have been closed by UNHCR, and they are vulnerable to detention and deportation, and still unable to return home. 


\section{The economic situation of refugees in Egypt}

Egypt's unemployment is estimated at around $20 \%$ (Sperl 2001). African refugees frequently experience racism on the streets and the media have been known to make xenophobic statements about refugees, who are seen as competing with Egyptians for work. However, 'the thousands of refugees living in Cairo are irrelevant to the explanation of the pressing economic and social problems found in Cairo' (SUDIA 2003). They are 'irrelevant' because they are consumers from the moment of their arrival, they receive remittances from abroad, they work in jobs not filled by Egyptians, and they receive very little assistance from UNHCR or the NGOs, which, in any case, represents income to Egypt in foreign currency. They, unlike many poor Egyptians, depend on the private sector for housing where rents are high. Refugees must pay school fees (when they can afford them). This expenditure directly benefits the local economy. And, unlike poor Egyptians, refugees have lost the social networks upon which they, like everyone everywhere, depend upon for support.

Assistance by NGOs is concentrated in Cairo and 'discourage[s] the dispersal of refugees throughout the country' (Ismail, 2002). Alexandria is the only other city in Egypt in which refugees receive (limited) assistance from UNHCR and churches. These services, which benefit at most a few hundred people, include education, health, food, and vocational training to help refugees obtain employment (as domestic workers, for example).

UNHCR gives monthly stipends to a limited number of refugees through its implementing partner Caritas. However, while the number of refugees in need has been increasing each year, funds have been decreasing. From 1997-2002, this money has declined from $\$ 2,928,129$ to $\$ 1,677,088$. If every recognized refugee (the only ones eligible for assistance) was given these funds on a per capita basis, they would have received only $\$ 186.34$ in 2002 . That amount would not even pay the average household's rent for three months. UNHCR attempts to 'target' the most 'vulnerable' (the aged, the infirm, minor children). In doing so it has arbitrarily cut off assistance to certain categories who may also be 'vulnerable', such as single men, all Sierra Leoneans, and all Liberians.

One can confidently say that refugees in Egypt belong to the poorest of the urban poor. Egypt calculates its poverty line on the basis of the cost of a diet sufficient to yield the daily minimum of 2200 calories. The annual cost of the minimum diet was estimated at LE4,439 for urban areas. 'This is considered as the food-based poverty line. Those who are below this line are referred to as ultra poor' (UNDP, 2003a: 115-6).

\section{Conclusion and key gaps in the literature}

Despite the quantity of literature on migration to and from Egypt, important gaps remain. While the focus of researcher seems to be turning away from migration studies, understanding the problems of people moving in search of work and security remains vital. Migration will remain a major response to poverty and human rights abuse for many years to come. There is a need to not study the past migration flows but to also anticipate and theorize future ones. 

East (Roudi, 2001). The national, regional, and global policy environment in which these movements and the conditions that cause them are enacted is another important area of study. Forced migration has been subject to some study but the articulation of this system with the conditions and structures in Egypt has not been addressed.

81 Cairo hosts one of the largest urban refugee communities in the world. A program of research that goes beyond the simple documentation of refugee policy and the position of Egypt and other host governments in the region is suggested. Research is to look at the intersection of policies that affect the conditions of refugees. The research may explore how refugees interact with the policy environment in this region and identify means of developing policies that enhance refugees' survival strategies and contributions to the host society and address the concerns of host nationals. A comparison between marginalized groups of nationals and refugees should be carried out.

\section{Acknowledgements}

I would like to thank Prof. Barbara Harrell-Bond, Distinguished Adjunct Professor and Mr. Randy Chrisler, Forced Migration and Refugee Studies Program, The American University in Cairo for information on refugees and their comments on early versions of this article.

\section{BIBLIOGRAPHY}

AFIFI, W. (2003) Research Report on Education for Refugees in Cairo. Unpublished Document, FMRS Library, American University in Cairo.

AL-SHARMANI, M. (2003) Livelihood and identity constructions of Somali refugees in Cairo. FMRS Working Paper 2. American University in Cairo.

http://www.aucegypt.edu/academic/fmrs/Reports/final.pdf

BRINKS, J.S. and SINCLAIR, C.A. (1980) International Migration and Development in the Arab Region. ILO, Geneva.

CAPMAS (1989) Housing and Population Census, 1986. Cairo.

CHOUCRI N. (1977) ‘The new migration in the Middle East: A problem for whom?' International Migration Review. 11(4), pp. 421-43.

CHOUCRI N. (1999) 'New perspectives on political economy of migration in the Middle East.' Appleyard, R. (ed.) Emigration Dynamics in Developing Countries. Volume 4: The Arab Region. pp. 19-43.

CLELAND W. (1936) The Population Problem in Egypt: A Study of Population Trends and Conditions in Modern Egypt. Science Press Printing Company. Lancaster, Pennsylvania.

Revue européenne des migrations internationales, vol. $19-n^{\circ} 3$ | 2003 
COOPER D. (1992) 'Urban Refugees: Ethiopians and Eritreans in Cairo', Cairo Papers in Social Science: volume 15, Monograph 2.

COOPER D. (1993) ‘A Needs Assessment of the Ethiopian and Eritrean Refugee Population' RSC Documentation Centre, Oxford University.

CORSELLIS J. (1993) 'Yugoslav refugees in camps in Egypt and Austria 1944-47', North Dakota Quarterly, 61(1) Winter: 40-54

DINGEMANS E. (2002) 'Educational Needs and Priorities for South Sudanese Refugees in Cairo.' Unpublished Report: FMRS, The American University in Cairo. Cairo, Egypt. Also Available at: http://www.aucegypt.edu/academic/fmrs/Research/Estherreport.pdf

EL ABED O. (2003) The Unprotected Palestinians of Egypt: An Investigation of Livelihoods and Coping Strategies' Unpublished Report. Forced Migration and Refugee Studies, The American University in Cairo. Cairo, Egypt.

FARRAG M. (1999) ‘Emigration dynamics in Egypt'. In R. Appleyard (ed.) Emigration dynamics in developing countries, Volume 4: The Arab region: 44-88. IOM and UNFPA.

GRINDELL R. (2003) A Study: Refugees' Experiences of Detention in Egypt, Unpublished Paper: FMRS, American University in Cairo.

ISMAIL I. (2002) Co-ordinating 'Humanitarian Aid' for Refuges in Egypt, June. Unpublished Report: FMRS, The American University in Cairo. Cairo, Egypt. Available at:

http://www.aucegypt.edu/academic/fmrs/Reports/iman.pdf

KAGAN M. (2002) Assessment of Refugee Status Determination Procedure at UNHCR's Cairo Office 2001-2002 Working Paper No. 1 FMRS, The American University in Cairo. Cairo, Egypt. Also Available at: http://www.aucegypt.edu/academic/fmrs/Reports/final.pdf

KAGAN M. (2003) 'Is the Truth in the Eye of the Beholder?: Credibility Assessment in Refugee Status Determination.' Georgetown Immigration Law Journal, Volume 17(3) forthcoming.

Library of Congress (2003) ‘EGYPT: A COUNTRY STUDY’ 6 June 2003. Available at: http:// memory.loc.gov/frd/cs/egtoc.html

No Author (2002) 'Withdrawal of Egyptian Reservations to the 1951 Convention Relating to the Status of Refugees' Prepared by Lawyers from the EOHR Refugee Legal Aid Project. Available at the American University in Cairo. Cairo, Egypt.

PETERSON N. (2001) ‘School's out,' Cairo Times. Volume 25 (5), 30 August - 5 September.

ROUDI N. (2001) 'Population Trends and Challenges in the Middle East and North Africa', Population Reference Bureau (PRB).

SELL R. (1988) 'Egyptian International Labor Migration: Towards regional integration.' International Journal of Middle East Studies. Vol 22 (3): 87-108.

SPERL S. (2001) 'Evaluation of UNHCR's Policy on Refugees in Urban Areas: A Case Study Review of Cairo' (EPAU 2001/07).

SUDIA (2003) 'Developing pathways into work for Sudanese Refugees: Labour Markets' Cairo.

TAKKENBERG L. (1998) The Status of Palestinian Refugees in International Law. Clarendon Press: Oxford.

ZOHRY A. (2002) 'Rural-to-Urban Labor Migration: A Study of Upper Egyptian Laborers in Cairo', $\mathrm{Ph}$. D. dissertation, University of Sussex. 


\section{NOTES}

1. -I would like to thank Prof. Barbara Harrell-Bond, Distinguished Adjunct Professor and Mr. Randy Chrisler, Forced Migration and Refugee Studies Program, The American University in Cairo for information on refugees and their comments on early version of this article.

2. - Ironically, these same refugees would have been recognised on prima facie grounds had they been in Kenya or Uganda.

3. -A Presidential decree signed in 2001 declared that Sudanese children of recognised refugees should be allowed to attend public schools. However, for the most part, this has not been implemented due to the requirement that each pupil should have a residency permit. In some cases, only residency stamped in a passport is accepted (Afifi, 2003; Dingemans, 2002).

4. -Steps have been taken, especially since 2002, to convince the Government of Egypt to take over its responsibility for status determination so that UNHCR may focus primarily on protection.

5. -The review of the preparatory work has also revealed that the international community did not decide to exclude Palestinian refugees from the general legal regime for the protection of refugees. Although the Arab states did not consider themselves primarily responsible for financing the relief effort, they were concerned that assistance or protection be extended to the Palestinian refugees irrespective of whether relief by the United Nations would continue to be provided. They therefore made it clear that the provision, included upon their request in the draft convention, was only to exclude Palestinian refugees temporarily (Takkenberg 1998: 66).

6. -More is known about this route because recently a group of Liberians who suffered serious security and economic problems in Egypt were trafficked to Israel. They are charged $\$ 3,500$, a sum that they are expected to pay after reaching Israel and getting work. They are warned that collectors will be there to ensure that they do pay. Many are apprehended by the Egyptian security, others by Israeli security and we learn about their cases when there is information about their detention either here in Egypt or from a human rights lawyer in Israel. At least one Rwandan refugee has also followed this route.

7. -This section is largely drawn from El Abed (2003).

8. -Palestinians studying abroad are granted one-year re-entry permits, as are those who have contracts for work abroad.

9. -The Egyptian government has waived the letter from the Sudanese embassy but must have all other documentation before a child can attend school.

10. -The Somali community maintains that there are at least 5,000 in Cairo.

\section{ABSTRACTS}

The Place of Egypt in the Regional Migration System as a Receiving Country. Egypt is stereotyped as a sending country in the migration literature. This article sheds some light on the position of Egypt as a migration receiving country, rather than a sending country. I explore the historical evolution of the Egyptian migration through defining its phases and the political powers shaping migration streams, and then I explore contemporary immigration streams and the government policies regarding the immigrants; both the voluntary and the forced migration. I also explore the role of the UNHCR and its policies regarding refugees and asylums in Egypt. The economic situation of refugees and their living conditions are investigated. 
La place de l'Égypte dans le système migratoire régional comme pays d'accueil. --L'Égypte est souvent présentée comme un pays d'émigration dans la littérature. Cet article met l'accent sur l'Égypte comme pays d'immigration, plutôt que comme espace de départ. L'auteur explore l'évolution historique de la migration égyptienne en définissant différentes périodes et acteurs politiques qui ont modelé les flux migratoires. Par la suite il analyse les flux d'immigration contemporains ainsi que les politiques migratoires gouvernementales, tant pour les migrants volontaires que forcés. Il aborde également le rôle du HCR concernant les réfugiés et les demandeurs d'asile, ainsi que leurs situations économiques et leurs conditions de vie.

El rol de Egipto en el sistema migratorio regional en calidad de país de acogida. La literatura sobre migraciones considera a menudo a Egipto como un país de emigración. Este artículo presenta, sin embargo, a un Egipto receptor de inmigrantes. El autor explora la evolución histórica de la migración egipcia e identifica los diferentes períodos y actores políticos que han contribuido a modelar los flujos migratorios. Son analizados a continuación los flujos de inmigración contemporáneos y las políticas migratorias gubernamentales dirigidas, tanto a los inmigrantes voluntarios como a los inmigrantes forzosos. Por último, el artículo aborda el rol de las acciones del UNHCR en favor de los refugiados y exiliados en Egipto, así como la situación económica y las condiciones de vida de estos últimos.

\section{INDEX}

\section{Geographical index: Égypte}

Mots-clés: conditions de vie, demandeurs d'asile, flux, HCR, historique des migrations, pays d'accueil, politique gouvernementale, politiques migratoires, réfugiés

\section{AUTHOR}

\section{AYMAN ZOHRY}

$\mathrm{PhD}$, Department of Epidemiology and Population Health, American University of Beirut, Beirut Lebanon. ayman.zohry@aub.edu.lb 